\title{
"She had to start thinking like a man": Women Writing Bodies in Contemporary Northern Irish Fiction
}

\author{
Maeve Eileen Davey
}

University of Ulster, Coleraine

Copyright (c) 2010 by Maeve Eileen Davey. This text may be archived and redistributed both in electronic form and in hard copy, provided that the author and journal are properly cited and no fee is charged for access.

\begin{abstract}
Studies of representations of the body in literature have become so well established as to no longer require extensive explanation or justification as a mode of criticism but, nevertheless, the choice to apply this particular mode of reading to contemporary Northern Irish fiction cannot be glossed over without comment. The body still remains a vastly under theorised aspect of Irish writing in general. The body, however, is an area of particular relevance to Irish fiction and particularly relevant to contemporary Northern Irish fiction in its depictions of national conflict, negotiations with slippery concepts of national identity and ambivalence towards the prevailing conservative cultural and religious climate. In many respects Northern Ireland remains a predominantly conservative, theocratic society in which women are still traditionally associated with the home, marriage and motherhood. However, many contemporary Northern Irish women writers navigate occasions in which the domestic and public spheres come into contact and collision, or the liminal space between them. This article focuses on three novels in particular, which span different genres, two decades and both the intra- and post-conflict periods: Give Them Stones (1987) by Mary Beckett, Hidden Symptoms (1987) by Deirdre Madden and Sharon Owens’ The Tavern on Maple Street (2005).
\end{abstract}

Key Words: Women's writing, Northern Ireland, fiction, Troubles, gender, body.

Resumen: Los estudios de las representaciones del cuerpo en la literatura están tan consolidados que su adopción como modelo crítico ya no requiere explicación o justificación alguna. No obstante, la aplicación de este modo de lectura a la ficción contemporánea de Irlanda del Norte aún requiere comentario puesto que el cuerpo sigue siendo un aspecto muy poco teorizado en la literatura irlandesa en general. Y sin embargo, es un área de especial importancia para la ficción irlandesa y en particular para la ficción contemporánea de Irlanda del Norte en lo que respecta a la representación del conflicto nacional, el debate en torno al huidizo concepto de la identidad nacional y la actitud ambivalente hacia el conservador clima cultural y religioso imperante. En muchos aspectos, Irlanda del Norte sigue siendo una sociedad predominantemente conservadora y teocrática en la que las mujeres siguen estando tradicionalmente asociadas con la casa, el matrimonio y la maternidad. Sin embargo, muchas escritoras contemporáneas de Irlanda del Norte se mueven por ámbitos en los que las esferas pública y doméstica entran en contacto y colisionan. Este artículo se centra en tres novelas pertenecientes a diferentes géneros, y cuya acción abarca dos décadas, durante y después del conflicto: Give Them Stones (1987) de Mary Beckett, Hidden Symptoms (1987) de Deirdre Madden y The Tavern on Maple Street (2005) de Sharon Owens.

Palabras clave: Escritura de mujeres, Irlanda del Norte, ficción, género, cuerpo. 
Studies of representations of the body in literature have become so well established as to no longer require extensive explanation or justification of exploring the body as a mode of criticism but, nevertheless, the choice to apply this particular mode of reading to contemporary Northern Irish fiction cannot be glossed over without comment. The body still remains a vastly under theorised aspect of Irish writing in general. The body, however, is an area of particular relevance to Irish fiction. Irene Gilsenan Nordin comments:

the body has a long tradition [in Ireland] as a powerful trope, reaching back to early Celtic Christianity, when the body was celebrated as a source of wisdom and beauty, to the fear of the body as a site of temptation and its strong negation in the Catholic tradition, to its exploitation as a force in the construction of Irish national identity, where the body was depicted as a landscape on which the nationalist drama was inscribed (Gilsenan Nordin 2006: 2)

The concepts of religion and nationalism and their relationship with the body in Irish writing as introduced above by Gilsenan Nordin are, of course, particularly relevant to contemporary Northern Irish fiction in its depictions of national conflict, negotiations with slippery concepts of national identity and ambivalence towards the prevailing conservative cultural and religious climate.

Taking this point further, Kathryn Conrad comments:

gender and sexuality are not only useful areas to examine closely when trying to understand the dynamics of power in the North: they are essential (Conrad 1999: 54)

Contemporary Northern Irish fiction may display ambivalence towards the north's prevailing conservative cultural and religious zeitgeist, but when it comes to the issue of gender relations and the concept of identity, the depiction of the female body and what it signifies continues to require close attention in contemporary Irish and Northern Irish writing.

\section{"The Common Good"? Delineation of the Private and Public Sectors}

Eavan Boland describes depictions of the feminine in Irish poetry in largely negative terms: the majority of Irish male poets depended on women as motifs in their poetry. The women in their poems were often passive, decorative, raised to emblematic status...She becomes the passive projection of a national idea (Boland 2006: 135).

In many respects, this appropriative identification of the feminine with the nationalist melodrama and the reduction of the female body to being merely decorative, while restrictive and even degrading, is also, unfortunately, in many respects unsurprising. Women have traditionally been identified with the nation and the home in modern Ireland, both of which function equally as a physical space and a mental state.

It is posited by Gayatri Spivak that a social dichotomy is perceived to exist between the "public" and "private" sectors, with the male public sector representing the "political", "social", "professional" and "intellectual", while the female "private sector" represents the "emotional", "sexual" and "domestic" (Spivak 1988: 3). This dichotomy has been particularly apparent in Ireland, a country with a constitution which explicitly linked women the home and the domestic, and used the words for woman and mother interchangeably. The women's movement in the south did much during the 1970s and 1980s to challenge this identification. Spivak's distinction, however, remains of crucial significance in a Northern Irish context, where, although the women's movement attempted to erode the cast iron distinction between woman and home, progress was severely hampered by the sectarian conflict, as stated by Linda Connolly and Tina O'Toole in their study Documenting Irish Feminisms: The Second Wave:

The development of the women's movement in Northern Ireland has been complicated and shaped by the impact sectarianism, religious differences and violence have had on women's lives since the late 1960s (Connolly and O’Toole 2005: 145).

In many respects, then, modern Northern Ireland remains a predominantly conservative, theocratic society in which women are still traditionally associated with the home, marriage and motherhood. However, many contemporary Northern Irish women writers 
navigate occasions in which the domestic and public spheres come into contact and collision, or the liminal space between them. This article focuses on three novels in particular, which span different genres, two decades and both the intra- and post-conflict periods: Give Them Stones (1987) by Mary Beckett, Hidden Symptoms (1987) by Deirdre Madden and Sharon Owens' The Tavern on Maple Street (2005).

\section{"Disturbing and oddly titillating": Sick Bodies, Liminal Spaces}

Contemporary Northern Irish women's writing frequently explores the liminal spaces between the private and domestic sectors, such as prisons, hospitals and bars and the relationships that begin and evolve within them. An example of this can be found in the recurrent symbol of the hospital in Hidden Symptoms, which is a signifier for both life and death, and acts as a strange microcosm of human experience. Theresa acknowledges that she "fear[s] hospitals with a primitive and childish fear" (1987: 117), which is in no small way related to the fact that her twin's body is taken to the nearby hospital for identification after his murder. Hospitals also unnerve Theresa, who tries desperately to maintain some sense of control and order in her life which has been thrown into chaos by her brother's untimely death, because hospitals are "where people's bodies, vulnerable at the best of times, were at their weakest and most pitiful” (1987: 117). The crux of the matter for Theresa is that "everything possible was done in hospitals to maintain life, and still people died" (1987: 117). Death is Theresa's ultimate fear because it is something she has no prospect of being able to control, and hospitals remind her of this unnerving fact constantly.

The hospital where Robert's sister Rosie has her baby is the same hospital in which Robert and Rosie's mother died, and therefore, like Theresa, Robert too associates hospitals with death. When Robert goes to visit Rosie after she has the baby, he thinks to himself:

how glad he would be when Rosie at last went home, for then he would no longer have to visit the hospital. His mother had died there, and returning to this place brought it back to him in a way in which he would never have believed possible (1987: 118).
But it is not just the hospital building but women's bodies themselves which are associated with both life and death in Hidden Symptoms. Rosie's husband, Tom, describes the experience of watching his wife give birth to their child to Robert:

it was rough, Bobby. I mean, it makes ye think...Yer own wife, Bobby...an' then...then ye think...yer own Ma. He paused again and gave a violent sob which startled Bobby, and cried, I mean, Christ, Bobby, it was fuckin' desprit! (1987: 112).

The experience of being an observer of the essentially visceral nature of birth has both unnerved and upset Tom, and, although Tom acknowledges that both Rosie and the baby are "grand", when he tells Robert that "it makes ye think", Tom seems to be referring to his guilt that the traumatic experience of birth had been the result of the physical aspect of Tom's relationship with his "own wife". He also seems to feel a strange, retroactive guilt that the fact of his birth meant that his mother had to go through something similar to Rosie. The identification Tom makes between his wife and his mother seems to aptly mirror the words of the old Irish constitution, which uses the words for woman and mother interchangeably, but this is not an identification female characters in contemporary Northern Irish women's writing encourage or even passively accept. In Give Them Stones, for example, Martha finds her husband "looking down at me with the same fondness that he used to have for his mother" (1987: 137). Martha is appalled, thinking, "I couldn't have that at all” and retreats into her bakery and busies herself with work to escape her husband's gaze.

Much of Give Them Stones, too, is devoted to the relationship between concepts of liminal spaces and disenfranchised masculinity. Before the Northern Ireland Civil Rights Association campaigned for change in the late 1960s and early 1970s, Catholic, nationalist men were usually marginalised by the Northern Irish state and often actively discriminated against and victimised. White, heterosexual masculinity acts, therefore, as an unusual signifier of victimhood in contemporary Northern Irish women's writing, which creates a strange dynamic in which the white male body, usually a symbol of strength, power and domination is rendered vulnerable, weak, and, in the case of Give Them Stones, ill. 
Seamus is enraged by the discrimination and injustice experienced by the Catholic community in Northern Ireland in the 1930s. When the police shoot and kill a young Belfast man who had joined the British Army and then decided to desert, Seamus "rushed out to see what was going on. He was angry and white in the face when he came back" (1987: 22). Despite the righteous indignation and disgust he experiences as a result of this example of police brutality, Seamus is powerless to do anything about it and both his anger and helplessness are reflected in the pallor of his face.

Seamus, is then interned, seemingly without reason, for the duration of WWII on "an old boat in Strangford Lough" (1987: 29), the fact that he is imprisoned in a boat in the water instead of in a building on land only emphasising the liminality of his position. For Seamus, this transitory prison then gives way to hospital without intermission. Martha's mother describes her now invalid husband as:

all thin and weak and not getting any better even though they've discovered a cure for TB now and other people are getting up and going home, but not Seamus. It doesn't work with him (1987: $60)$.

Seamus's spirit is largely broken in the prewar years, unable to find employment, powerless to make decisions regarding his family due to his lack of economic input into the running of the household, and full of impotent rage and misery at the discrimination he and the other nationalist men are victims of. His ailing mental and emotional state is then reflected in his disease-ridden body, and even his wife suspects that there is a connection between the two. Martha, who had idolised her father as a child, goes to visit him in the hospital and when she sees him for the first time in several years, she is appalled:

He didn't look as I had pictured him now and again down the years. He was thin and limp. His eyes closed from time to time...he held out his hand for me to shake but it was so cold and dead I wanted to drop it straight away (61).

Martha's father has become an increasing irrelevance in the lives of his wife and children; even the daughter who once idolised him recoils from his "dead" touch. Whatever virility Seamus might have been possessed of in the years before the war has been completely sapped by his internment and subsequent illness, as indicated by his "limp" body. Seamus's illness disgusts his daughter and frustrates his wife, who comments with increasing frustration:

Your father just doesn't want to get better. He's happy lying there with me tearing across town to see him...They've done everything for him and he won't get better (62).

When Seamus eventually succumbs to his illness, Martha states, "I didn't feel sad" (65). Martha's lack of feeling, however, is not indicative of particular callousness: Seamus's inability to provide for the family in the public sphere combined with men's ability to comfortably slot into the domestic sphere means that he has been an absent figure from his wife and children's lives. His death is merely the only means by which he can escape the shadowy, liminal spaces he has inhabited for the last years of his life is a relief for all concerned.

\section{“So different and yet still human!": Women Writing Men Thinking Women}

The appropriation of the feminine in order to identify it with national concerns as formulated by Boland inevitably often seems to also imbue the female body with the status of victimhood. Madden, however, seems keenly aware of this requisitioning of the feminine in Hidden Symptoms, and explores the northern male writer's attitude towards women through the views held by Robert, a Belfast born and bred arts magazine journalist. Robert has uncomfortable relationships with the women in his family - he argues constantly with his mother until her death and he looks down on his sister:

There was a smell, he thought, a smell in his sister's house: not a bad smell, but the smell of people and cheap food: a smell of poverty. He felt it clinging to his clothes and skin, and he removed it immediately on his return with a hot shower and lots of male toiletries which smelt bitter, sexy and expensive (1987:18).

Robert defines his sister Rosie by the working class area of Belfast in which she lives - its smells, its people, its diet - and he visibly cringes at her "attitude of good hostess" when he brings a friend round to visit, in a move akin to the identification of the feminine 
with the nation. Robert seeks to categorise and define women so, like his sister, he can look down on them, or like his girlfriend, Kathy, he can patronise them, criticising their choice of friends and the decisions that they make. Robert is undeniably fond of and on some level infatuated by Kathy. As he watches her put on her make-up, he thinks: "If there were really such a thing as magic...it had something to do with women's bodies” (1987: 57).

However, despite the intimacy between them, Kathy's body is for Robert just an example of all "women's bodies" and he admits that "the otherness of women fascinated him...so different and yet still human!" (1987: 56) Robert finds it almost impossible to relate to his mother, sister, girlfriend or Theresa on a personal, human level - to him, they are in many respects mere representatives of womankind in general and their femininity simultaneously attracts and repels him. Robert acknowledges that:

He had never felt any real unity with any woman...He had drifted away from all the girls he had ever known with no more ultimate intimacy that there had been when they first met (1987: 66).

Yet, despite his lack of unity or intimacy with any of the women he has known, Robert is, nonetheless, shrewd enough to read women's body language and manipulate them accordingly. The night before his mother's funeral, Robert seduces a girl and brings her back to his flat where he "frighten[s] her with his passion" (1987: 78). When she sees the black tie laid out in his bedroom, she jokingly asks him who has died. When Robert answers her truthfully and tells her his mother is dead, he feels the girl's "body stiffen, and her voice changed" (1987: 79). Robert understands that this physical reaction is caused by the girl's empathy with what she imagines to be Robert's distress and with the horror of the situation. He does not want to share his pain or discuss his feelings with the girl, though, so he lies to her instead and tells her his mother died a year ago and feels "her body relax again" (1987: 79). Although he regrets "his cowardly lie", Robert's regret does not make him change his promiscuous behaviour nor does it make him more inclined to foster any level of intimacy in his personal relationships, because, for Robert, the physical and the emotional are completely divorced.
This emotional detachment and basic misogyny is also true of Liam Bradley in The Tavern on Maple Street, whose primary purpose in the narrative is to serve as an exaggerated parody of an arrogant male writer. Theresa challenges Robert's affected detachment from Northern Irish politics in Hidden Symptoms, and in The Tavern on Maple Street Owens satirises Liam's callous attitude towards both his wife and the city he calls home. Liam's wife, Betsy, thinks she is "bored with Belfast" and hatches a plan to move to Dublin. Liam, however, is completely adverse to the idea, firstly because he condescendingly considers it ludicrous that his wife "who was reared in a Falls Road, thought she was the equal of the sons and daughters of the old-money elite of Dublin" (2005: 28). Another reason Liam refuses to move to Dublin, or anywhere else for that matter, has nothing to do with any sentimental attachment to his hometown - it is because he considers Belfast to be his "Unique Selling Point" (2005: 30 ) and since he has given "so many interviews over the years declaring he would never leave Belfast" that he worries "what would his fans think of him if he decamped to the champagne set in Dublin now?" (2005: 31).

Liam has no empathy for his wife of ten years, whom he contemptuously describes as having an accent "as rough as a vulture's arse" (2005: 29) and who now reminds him of a stripper, which is problematic, because in Liam's hypocritical opinion "strippers were fine for one night stands but [he] didn't want to be married to one" (2005: 32). Liam knows that if he ever managed to make it big that he would "drop Betsy like a hot potato" (2005: 32 ) and the only emotion he can bring himself to feel for Betsy is "pity", which, in Liam's opinion, is "better than feeling nothing at all for her" (2005: 30). Although he acknowledges some of his writing to be "perverted", Liam is adamant that the objectification of women in his novels is "harmless, soft-focus and fun" (2005: 34). Although Liam meets the requisite unhappy ending, thrown out by his wife, drunk, alone, soiling hotel bedrooms and punched in the face by Jack for making advances towards Lily, he achieves no clarity and insight into his own behaviour. As the novel closes, Liam is on "the first flight to somewhere warm that sold cheap liquor" (2005: 308), having been double-crossed by his 
long suffering literary agent who has finally had enough of Liam's selfish, unreliable behaviour and having decided he is "better off without [women]” (2005: 307).

\section{"Angular and Androgynous": Violence, Gender Confusion and Role Reversal}

Madden and Owens' novels both showcase a particularly virulent misogyny and physical disgust towards the feminine from Northern Irish male writers, but it should also be noted that the victimization and resulting emasculation of the male body as a result of violence is just as prominent a theme in contemporary Northern Irish women's writing. This is indirectly explored in Beckett's Give Them Stones and is also particularly the case in Hidden Symptoms, where Madden employs the motif of fraternal twins - one female, one male, one alive and one dead as a result of sadistic, sectarian violence. Francis, the male twin, becomes configured as feminine both as a result of the traumatic and violent death he experiences at the hands of a loyalist gang and in the way he is remembered by his sister and friends. Even Francis's name is ambiguously genderless; with the slightest variation in spelling Francis becomes the feminine Frances. He is characterised as being religious, mild and otherworldly. Theresa notes that he responds with "sensitivity...to the beauty around him" while they are on holiday in Italy and Kathy describes him as "genuinely shy...gentle, eccentric" (1987: 62-63). Robert, too, notes that a photograph of Francis "looked so like Theresa that Robert shivered.” (1987: 132) Francis' gentleness and his fey lack of materialism, epitomised when he drops out of university to work in a supermarket because it "leaves [his] mind free for higher things" (1987: 63), when combined with Francis's resemblance to his sister and the gruesome, violent manner of his death at the hands of a male, loyalist gang has the undeniable effect of feminising him in the narrative.

There is also an undeniable connection between Francis and Francis of Assisi, with their shared name, religious conviction, gentleness, association with Italy and scorn for worldliness and materialism but the identification of Francis with religion is one that Theresa is ambivalent about. Since her brother's murder, Theresa feels that "God [is] her only link with Francis and if she lost God she lost Francis” (1987: 52) but her feelings towards God are largely negative and she describes God as "cruel, hated" (1987:52) but, crucially, also as "real" (1987:51). And when Theresa's mother asks if Theresa thinks of Francis as a martyr, Theresa's reply reveals the true depth of her ambivalence:

I suppose he was ... they just killed Francis because of his religion, he had no choice...We don't know anything at all about what happened to him, only that ... I suppose he was a martyr (1987: 42-43).

The use of "suppose" twice in quick succession, together with Theresa's declaration that they "don't know anything at all" about the true circumstances of Francis' death undermines the concept of martyrdom in the context of the Northern Irish Troubles. This is hardly a point without wider political implications in a novel published in the same decade as the deaths of ten republican hunger strikers, who were instantly memorialised as martyrs in murals, songs and annual commemorations. Theresa's attitude insists that there is nothing heroic in sectarian violence or laudable about dying for your beliefs.

Theresa's attitude towards her brother's death, however, may reveal more than just her political and religious views on the matter. Elmer Kennedy Andrews has suggested that the relationship between Theresa and Francis is also coloured by the suggestion of incest. Kennedy Andrews points to incidents in the novel which reveal Theresa's "unusual passion" for her brother such as when she calls Robert "Francis" when her puts her to bed to conclude that:

The veiled hints of a repressed incest narrative (which are reinforced by a reading of Madden's second novel, The Birds of the Innocent Wood) would explain Theresa's anxiety to place to memory of Francis under taboo and envelop it in the unspoken (2002:148).

The relationship shared by Theresa and Francis remains, therefore, unclear. Their relationship as siblings may not be a sufficient explanation for Theresa's overwhelming grief at her brother's death, especially a year after the event. But whether the connection between them as twins would have been strong enough to have caused Theresa such emotional distress or whether the answer lies in a more oblique sexual relationship between the two is never fully revealed. 
Theresa, however, conversely, does become both less feminine and less human following her brother's murder, at least in so far as Robert is concerned. When Robert first meets her, he is immediately taken aback when she inadvertently criticises a magazine article he has written to his face. The fierce intelligence and aloof integrity Theresa displays make Robert distinctly uncomfortable:

Kissing Theresa, he thought, would be dangerous and painful; it would sting the lips as it did to kiss a poisoned Bible or a religious statue daubed with Belladonna in a Jacobean tragedy. To embrace her would be like driving an iron spike into his chest...He still felt that it would be eerie and unnerving to discover by experience that Theresa's body was as warm, soft, mortal and sexual as that of anyone else (1987: 65).

The image of the iron spike is unmistakeably phallic - Theresa's demeanour is not passive and is not therefore pleasing to Robert, so he imbues her with masculine qualities. Robert's masculisation of Theresa is made explicit when Robert decides Theresa is "a right oddity...in a way she wasn't really like a girl. Never before had he met someone so angular and androgynous" (1987: 64.) The masculine attributes Robert imbues Theresa with are further underlined in the connections he makes in his mind between Theresa and a tiger lily, which Robert describes as a "savage, phallic, heartless flower" and between Theresa's eyes and those of "an indolent cobra" (1987: 64).

With the revelation of Francis' murder at the novel's climax, Robert looks at the hysterical Theresa and "wished that he could take her in his arms and weep, too, but his usual revulsion for her body was now compounded by fear" (1987: 139). Theresa, through the loss of her twin, represents death and, through her faith, an Old Testament influenced concept of religion in the novel - one of sin, suffering, judgement and damnation. Theresa's body, therefore, is strangely sacrosanct and, to Robert at least, untouchable, reflecting that of the resurrected Christ figure in John's Gospel who tells Mary Magdalen "Noli me tangere”.

It is not just in Robert's undeniably skewed perspective, however, that Theresa is endowed with these typically masculine characteristics. When Theresa talks about the people who killed Francis to her mother, she speaks "roughly" as her mother "lay wailing on the sofa" (1987: 73), with an obvious contrast being drawn between the self-possessed, angry Theresa and her mother's weak, directionless grief. Obsessed with "morbid fantasies concerning her mother", Theresa is like the Oedipal protagonist in a tragedy; her brother and father are both dead and she has become obsessed with protecting her mother.

Theresa's guilt is that she has survived when Francis has not and the trauma of her brother's murder has made her a victim of fear, which means that she constantly worries about what might happen to her. This particular symptom is shared by Theresa's mother - the one night Theresa neglects to be responsible and ends up passed out drunk at Robert's flat without telling her mother she will not be home, her mother berates her:

I can't understand how you could do this to me, Theresa, I simply can't understand ... Sorry's not good enough. After what happened to Francis, if you had thought at all you'd have known that I'd be distracted (1987: 108).

Although Theresa tries to tell herself her fears are "foolish and childish", both women are equally aware that it is "not an illogical fear, for Francis had been killed and Belfast was small: it might well happen again" (1987: 50). But in the absence of anyone else, Theresa's guilt causes her to take on the traditionally masculine role as defender of what is left of her family, at the cost of her own happiness. If an identification between Francis and Francis of Assisi is accepted then perhaps a similar identification can be made between Theresa and St. Teresa of Ávila, whose motto "Lord, either let me suffer or let me die" would certainly seem to be one that the griefstricken Theresa could identify with in Hidden Symptoms.

"In the middle of the dust and panic": Victimhood and the Male Body in Women's Writing

Victimhood and the horror and injustice of violence wrought on the body, especially the bodies of the defenceless, are important themes in Northern Irish women's writing. Interestingly, however, in women's writing it is often men who are injured as a result of the conflict. There are, of course, some notable exceptions but many, and perhaps even the 
majority, of the victims of sectarian violence in contemporary Northern Irish women's writing are men.

This is not to suggest that the violence does not have insidious consequences on female bodies in contemporary Northern Irish women's fiction as well. Nor do I mean to imply that there is something unusual about men being the focus of the sectarian violence in Northern Ireland. The predominance of male involvement as either perpetrator or victim of sectarian violence is borne out by the Legacy of the Troubles (2007) report, which asserts that "Overall, men were more likely to report experience of the Troubles than women...a higher proportion of men than women reported having been a member of a paramilitary group." (Muldoon, Schmid, Downes, Kremer and Trew 2007: 22). However, having white, heterosexual masculinity as a signifier of victimhood in contemporary Northern Irish women's writing sets up a particularly interesting encounter with the masculine body, which is made vulnerable, stripped of its potency and, like Francis in Hidden Symptoms, essentially castrated. Robyn Longhurst argues that "men are often understood to have secure (autonomous) bodily boundaries - bodies that are in control" (Longhurst 2001: 2) and that "heterosexual, "white", "able-bodied men" in particular have "bodies that tend to be constructed and understood as hard and strong" (Longhurst 2001: 6). The preoccupation contemporary Northern Irish women writers have with the male body as both the perpetrator and victim of the culture of paramilitary violence, serves to explore, subvert, undermine and ultimately reveal this stereotyped image of white male virility and strength to be little more than an outmoded, colonial façade.

In Owens' The Tavern on Maple Street, Jack's hair

had been pure grey since the age of nineteen, when it lost its rich black colour overnight ... Some people said it was because he was standing up against a dry-stone wall in December 1984, when a huge bomb exploded on the other side, and the shock made all the colour in his crowning glory fade away (2005: 7).

This interlude has something of a magical realist bent but the danger to Jack and the trauma caused to him and his wife Lily as a result of the bomb is no less real because of it. Jack is temporarily left partially deaf afterwards but because “stress counselling hadn't been invented in those days...the police told him how lucky he was, and to take himself home and forget all about it" (2005: 8), while Lily "almost die[s] of shock herself when she heard the bomb go off, because she knew her beloved Jack was in the affected area...in the middle of the dust and panic" (2005: 8). As a result of the trauma the couple experience, the tavern that Jack then inherits from his uncle becomes

like a refuge from them, where they could hide themselves away from Belfast and the world. They decided not to hire staff or increase trade in any way. As soon as they became successful, the paramilitaries would come looking for a share of it, they decided. So, they kept a low profile, and life went on (2005: 5).

Although, in The Tavern on Maple Street, Jack survives the bomb blast relatively physically unharmed, his status as almost-victim leaves him as a somewhat emasculated figure nevertheless. It is not just the protection-racket paramilitary gangs Jack is afraid of: as the ultimately signifier of emasculation, Jack is also shown to be afraid of women. When Jack and Lily take in the tavern's new barmaids as their lodgers, he admits to his wife that the loquacious, effervescent Bridget "frightens the life" (75) out of him and Jack also feels

quite shy with all these young girls running about the place. He was afraid to get dressed without locking the bedroom door in case one of them burst in and caught him in his shorts (2005: 178).

In Jack's household, it is the male body that provokes a sense of shame and it is not the girls who are terrified of the possibility of seeing Jack's naked body, but Jack himself who is terrified of them seeing him in a vulnerable state of undress. One of the very few times in the novel when Jack takes any assertive action whatsoever, by tackling the drunk and abusive Gerry Madden, he only manages to throw one punch before he is arrested by a passing policeman. To complete the indignity, Jack also gets hit in the head by a scalding cup of tea thrown from the window during the scuffle, so this rare attempt to assert his masculine authority leaves him with nothing but "a thin blue bruise on his forehead” and “a police caution” (2005: 134).

Lily, on the other hand, is a paragon of 
delicate, modest femininity: a "sensitive woman" (2005: 5) who dresses like a Victorian lady in "long swirling skirts and dainty black button boots" (2005: 32) and "linen blouses" (2005: 32) and who coyly reveals no more flesh than "a tantalising glimpse of [her] slender ankles" (2005: 32) to anyone but her husband. However, when Dublin-based developers come to Belfast with big plans for a huge, new shopping mall, the previously timid Lily asserts her agency outside the private sphere by attempting to fight the developers in order to save her home and business. Accordingly, upon entry into the masculine, public sphere, Lily takes on more assertive, masculine characteristics as the novel progresses and the emasculated Jack reveals himself to be totally incapable of putting up a fight in order to save their beloved tavern from the hands of the developers who want to flatten it. Lily, while she shares Jack's distress and wants "to run screaming into the street, crying and complaining about the injustice of everything” (2005: 42) nonetheless realises that "she had to start thinking like a man. Practical solutions were required now, not just useless emotions" (2005: 43). It is Lily who puts up a fight to save the tavern and who is at last able to admit that the reason she and Jack have loved the tavern so much is because

it meant that she and Jack could isolate themselves from other people. It was their excuse for not spending time with their difficult families. It had protected them from the stresses of the workplace, from friends and acquaintances that might require some of their attention. They had been rather selfish in a way (225).

This admission and Lily's subsequent ability to let go of the tavern without regret differentiates the strength of character and resolve she possesses from the displays of masculine strength in The Tavern on Maple Street, as epitomised by the vulgarity of Liam, the drunken boorishness of Gerry and the sleaziness of Richard. Lily may proclaim that she has to "start thinking like a man" but a huge gap exists in Owens' novel between Lily's strong femininity and the obviously satirised, negative examples of male strength and assertiveness.
"I had kept my head down long enough": Journeying towards Strength and Subversion

Martha in Beckett's Give Them Stones offers the reader a particularly interesting portrayal of a woman's journey from the passive acceptance which characterises her youth to the strength, subversion and defiance that come with age and experience. This journey is all the more interesting in that Martha reaches the height of her strength and awareness as an older woman, when older women are often marginalised figures in contemporary writing and in modern culture more generally. Sally Chivers has commented on the "norms" when it comes to the representation of older women as "used up, decrepit, asexual and frail" (Chivers 2003: ix) and the "odious stereotypes that fix old age as a time of disease, decline, and death" (Chivers 2003: x). In Beckett's novel, although Martha experiences a loss of confidence in herself now that her husband and children no longer need her and subsequently reflects if she is "not baking bread I am nobody and nothing" (1987: 147), the stereotypes are nonetheless completely subverted as Martha makes an effective and determined stand against victimhood. Give Them Stones begins with Martha sitting alone at her fireside in the evening, the stereotypical image of an older woman whose children have grown and left her. This somewhat pathetic picture is then sharply contrasted with Martha's actions when she hears a shot being fired outside, and like Lily in The Tavern on Maple Street, fiercely protects her home, even though Martha, unlike Lily, feels no particular sentimental attitude towards the place. Instead of cowering inside in fear by the fireside or calling to her husband, Martha runs "out on to the dark street to see what was happening” (1987: 9) and, even when she sees paramilitaries standing over a boy they are inflicting a punishment beating on, Martha still does not retreat inside, instead "shout[ing] at them what did they think they were doing” (1987: 9).

The boy's body and Martha's home have both been violated by this act, along with Martha's acceptance of the status quo. After the boy is taken away in an ambulance and the 
crowds disperse, Martha pragmatically busies herself bringing "out buckets of water and a yard brush and washed and washed at the place" (1987: 9). All the while she resolves not to pay protection money to the local paramilitaries any longer because: "I had kept my head down long enough...But I'd have no respect for myself if I didn't let them know what I thought” (1987: 10).

Thus begins Martha's one-woman crusade against the lawless brutality of paramilitarystyle community policing. As in the case of Lily in Owen's The Tavern on Maple Street or Theresa in Madden's Hidden Symptoms, there is an assumption that for a woman to make the decision to take a stand, to resist and to speak out against injustice in society will necessarily entail a degree of masculisation. And, just as Jack in The Tavern in Maple Street and Francis in Hidden Symptoms become emasculated in contrast to their stalwart wife and sister, so too do the men in Give Them Stones. The boy who is being kneecapped at the beginning of Beckett's novel, for example, weakly cries “Don't do it again. Don't, don't. Oh Mammy, Mammy, I'm going to be good" (1987: 9), before fainting from the pain of his injuries. The suggestion in the boy's semi-conscious moaning appears to be that he has been the victim of pain inflicted by a woman previously, namely his mother, which again places the feminine in a role of power in contrast to male submissiveness.

Even as a young woman, Martha begins to move away from a romanticised view of the put upon, suffering nationalist male to a position of strength and defiance. The realities of economic survival, the example of her mother and aunts, and the death of romance caused by her abortive relationship with Hugh Mulholland mean that Martha has become hardheaded and pragmatic, and this is reflected in her reaction to her father's death. In fact, is only Martha's brother, Danny, who experiences real sorrow at the news of their father's death:

poor Danny cried and cried. He stayed in his bedroom and he ate nothing...after Mass when he was to take his corner of the coffin he couldn't stand. His legs folded up under him and two men had to half-carry him out of the church (66).

Martha's pragmatism is again reflected in her marriage to Dermot. Her aunts deter her from pursuing a relationship with Hugh Mulholland because, according to them, Hugh's family are "riddled with TB" (1987:53), but when she meets Hugh a few years later, and finds out that he is healthy and married, Martha goes home and "cried and cried with such a pain at my heart” (1987: 71). Realising it is too late for anything to ever happen between her and Hugh, her subsequent regret and her feelings of jealousy about Mary Brigid's marriage mean that when Martha meets Dermot she is in a pragmatic rather than romantic frame of mind. She admits that she "wasn't expecting to meet anyone handsome", so even though Dermot, in Martha's opinion “didn't look much really - mousy hair, greyish eyes, not tall” (1987: 74), she agrees to meet his mother. When Martha sees the house Dermot lives in with his mother with its gas cooker and oven, Martha realises she "knew then that [she] wanted to marry Dermot" (1987: 76).

Dermot is passively accepting and law abiding. Even his mother, who is trying to persuade Martha that Dermot would be a good husband, describes Dermot like he is a child: “He's a good boy, you know...I've always looked after him and kept him lovely. He likes things to be nice - clean and tidy” (1987: 79). As the Troubles worsen, Dermot pleads "like a child" with his wife, "We'll never leave, sure we won't Martha?” (1987: 137) Martha, however, just shrugs, encompassing her unsentimental detachment from the house itself and her increasing alienation from the community she lives in. Many of Martha's neighbours at least tacitly support the brutal paramilitary policing of their community because the anti-social behaviour of shoplifting and robbery is "a torment to the place" (1987: 141). Martha, however, although she acknowledges that the Provos "were the only people I could hear of that the English paid any heed to" (1987: 142) is strongly against their actions:

when the Provos took it on themselves to bring law and order to the district I got angry. Everybody knew there were boys breaking into houses or tormenting old people...I didn't think anybody had the right to take it on themselves to shoot them in the leg or beat them with hurley sticks or break their arms with concrete blocks. It seemed to me to be savagery (1987: 141). 
Martha's vocal opposition to this violence means that she is "well-known" for holding this view and she believes that this is the reason the paramilitaries kneecap the boy against the wall of her house. When they call for their weekly monetary contribution from Martha's business, she refuses to pay. Her strong, masculine defiance is in stark contrast to the reaction of the men - her husband panics and "alarm" registers on the face of the man who has been sent to collect the money. Even when more men arrive to burn down the house and shop, Martha, like her mother, says nothing but gathers up some of their belongings in a suitcase and silently watches while her "livelihood and habitation disappear in flames flying up into the sky". Her implacable detachment is sharply contrasted with Dermot's sentimental attachment to the domestic sphere, and who pleads with the men, "Not the house, not the house...I never did you no harm" (1987: 144) to no avail. Even when Dermot capitulates and realises they have no other option but to go to the house of one of Martha's relatives, he feebly complains that the walk to her sister's is long.

Edna Longley comments:

Gonne, Markievicz and Maeve the warriorqueen have enjoyed a new lease of life in Northern Republican ideology. Perhaps we too readily assume that it's always a good thing when passive versions of women are transformed into active ones...Both have political uses (Longley 1994: 189).

Give Them Stones is undeniably a political novel in some respects. Beckett's version of life for the working class Catholic, nationalist community in Northern Ireland for the half century between the 1930s and the 1980s where the narrative closes is characterised by discrimination, oppression, a lack of discernible opportunity and the omnipresent threat of death or incarceration. Blame for this is often squarely laid upon the colonial British Army presence and the indifferent RUC police force in the novel. However, despite its political overtones, Give Them Stones remains firmly realist in character and, as such, Martha's subversion does not end in glory and victory for her. She is anxious for her safety following the reprisal for her refusal to pay protection money and admits to herself: "I couldn't be expected to be brave all the time. I couldn't conduct a campaign all on my own.”
(1987: 150) Martha, then, is obviously not a "warrior-queen" in the canon of "Northern Republican ideology". But nor is she submissive and defeated by what happens.

As a result of the civil rights movement and the rights Catholics won in the 1970s, Martha and Dermot get allocated a new house when they are burnt out of the old one and Dermot also ensures that they receive compensation money. Martha even decides to make enquiries about opening a new bakery in rented premises, even though she is aware that renting a shop in a public location might not guarantee the safety of her new business because "the public were too frightened and turned their heads away and I didn't blame them” (1987: 150). Like Madden's claustrophobic, bleak vision of 1980's Belfast, Beckett too portrays a place rife with sectarianism and violence, but one in which life must continue nevertheless. Moreover, by showcasing the services and aid which Martha and Dermot are able to avail of at the end of the novel, Beckett opens up the tenuous prospect of optimism and nationalist faith in the state itself, which, up until this point in the novel, Martha has openly reviled.

\section{Conclusion}

Northern Ireland has a long way to go before it can emerge from decades of trauma and shed the endemic collective memories of horror and fear. The distance Northern Ireland still has to go in order to achieve this, if it is in fact achievable, is reflected in contemporary Northern Irish women's writing, along with a palpable concern that the only means for women to assert agency or strength within a culture so rigidly constructed along masculine, militaristic, religious and conservative lines is to necessarily become more masculine. When masculinity is associated with such negative concepts, it is hardly surprising that the notion of having to become more masculine is not one which appeals to many women.

But victimhood is just as troubling a concept in contemporary Northern Irish women's writing as that of strength. David Canter comments: "What our consideration of the violated body shows is the notion of self is sometimes a difficult fiction to maintain. It is challenged every time the body is violated in any way" (Canter 2002: 65). What the body could then potentially become representative of in Northern Irish fiction, if it is removed from the familiar context of violence, abuse and 
death, is still unknown and that uncertainty creates a palpable anxiety.

But finding the mental and even then fundamental physical space in which to retreat from the dominant sectarian politics of the state and from the insidiousness of the violent conflict is a difficult and potentially even impossible task. The state itself is widely perceived as liminal, contested and constantly in transition. Jennifer Jeffers comments "the body and what we like to call "self", according to Deleuze and Guattari, is a mere threshold" (Jeffers 2002: 47). Bodies, in this sense, then, are liminal also. Scott Brewster draws a parallel between the contested state and the contesting body politic in a Northern Irish context:

It might be argued that Northern Ireland - a territorial and signifying space whose meanings and boundaries have been so violently contested, a body politic sustained and wracked by anomalous and permeable partition - has been in a condition of abjection since its foundation. Against this disorder, Northern Irish writing has often been posited as a purifying, redemptive force, able to "hold a plea" with the rage of conflict and crisis (Brewster 2006: 21).

This link between the Kristevan concept of abjection as the condition of marginalized people and the space of abjection being the place which the marginalized inhabit is by no means a new one, but Brewster is one of the first critics to apply the concept so explicitly to the context of contemporary Northern Irish writing. Brewster goes on to argue that the positing of Northern Irish fiction as purifying and redemptive in the face of the violence it attempts to portray is inaccurate and limiting.
Like Brewster, then, my central argument is that there is no one, overriding, simplistic way in which contemporary Northern Irish women's writing refers to or deals with the problems posed by physicality and the body, within the context of civil conflict and sectarian violence which is both a backdrop and a necessary element of much contemporary Northern Irish writing. There are multiple approaches, some positive and redemptive, others horrifying and despairing and yet others which approach the body from the stance of Otherness, difference, somatophobic disgust and alienation.

Contemporary Northern Irish women's writing is, through an interrogation of traditional binaries and dichotomies and through negotiations, encounters and dialogue, nonetheless beginning to explore some of the possibilities for re-configuring the body, as well as examining the inevitable limitations, ramifications and even perversions of a mindset which associates the body so closely with politics and conflict. In doing so, contemporary Northern Irish women's writing is making crucial inroads towards considering how a culture, which was for so many years forcibly indifferent towards injury, torture and suffering, can begin to re-evaluate its attitudes towards the physical. Northern Irish women's writing may not always transcend the restrictive identification of the body as a site of conflict, the victim of pain and abuse and the location of gender and racial confusion but it does point towards the potential for new and interesting readings of the body in relation to motherhood, marriage, strength, assertiveness and faith.

\section{Works Cited}

Beckett, Mary. 1987. Give Them Stones. London: Bloomsbury.

Boland, Eavan. 2006. Object Lessons: The Life of the Woman and the Poet in Our Times. Manchester: Carcanet Press.

Brewster, Scott. 2006. "Abject State: Ritual, Waste and the Exile of the Body in Northern Irish Poetry” in Irene Gilsenan Nordin (ed), The Body and Desire in Contemporary Irish Poetry. Dublin, Portland: Irish Academic Press.

Canter, David. 2002. "The Violated Body" in Sean T. Sweeney and Ian Hodder (eds) The Body. Cambridge: Cambridge University Press.

Chivers, Sally. 2003. From Old Woman to Older Women: Contemporary Culture and Women's Narratives. Ohio: Ohio University Press. 
Connolly, Linda and O’Toole, Tina. 2005. Documenting Irish Feminisms: The Second Wave. Dublin: Woodfield Press.

Conrad, Kathryn. 1999. "Women Troubles, Queer Troubles: Gender, Sexuality, and the Politics of Selfhood in the Construction of the Northern Irish State” in Marilyn Cohen and Nancy J. Curtin (eds) Reclaiming Gender: Transgressive Identities in Modern Ireland. MacMillan: London.

Gilsenan Nordin, Irene. 2006. "Remapping the Landscape: The Body as Agent of Political, Social and Spiritual Empowerment in Contemporary Irish Poetry” in Irene Gilsenan Nordin (ed), The Body and Desire in Contemporary Irish Poetry. Dublin, Portland: Irish Academic Press.

Jeffers, Jennifer M. 2002. The Irish Novel at the End of the Twentieth Century: Gende[r], Bodies and Power. Palgrave: New York.

Kennedy-Andrews, Elmer. 2003. Fiction and the Northern Ireland troubles since 1969: (de-)constructing the north. Dublin : Four Courts.

Longhurst, Robyn. 2001. Exploring Bodily Boundaries. London, New York: Routledge.

Longley, Edna. 1994. The Living Stream: Literature and Revisionism in Ireland Newcastle: Bloodaxe Books.

Madden, Deirdre. 1987. Hidden Symptoms. London: Faber and Faber.

Muldoon, Orla, Scmid, Katharina, Downes, Ciara, Kremer, John and Trew, Karen. 2007. The Legacy of The Troubles: Experience of The Troubles, Mental Health and Social Attitudes. Belfast: School of Psychology, Queens University Belfast.

Owens, Sharon. 2005. The Tavern on Maple Street. Dublin: Poolbeg.

Spivak, Gayatri Chakravorty. 1988. In Other Worlds: Essays in Cultural Politics. New York \& London: Routledge.

Received 1 December 2009 Revised version accepted 16 January 2010

Maeve Eileen Davey is a final year PhD student at University of Ulster, Coleraine, researching a thesis on Marginalised Bodies, Liminal State: Body, Gender and Place in Contemporary Northern Irish Fiction. She holds an undergraduate degree in English Literature and Philosophy from University of Glasgow and was the recipient of the IASIL postgraduate scholarship in 2009. 